\title{
Effects of domestic pollution in Izmir Bay (Turkey)
}

\author{
A. Kocataş \& R. Geldiay \\ Ege University, Bornova-Izmir, Turkey
}

\begin{abstract}
The untreated domestic sewage of 650,000 people and wastes from industries and ships are discharged into the inner Bay of Izmir daily. Since May 1977 physico-chemical and biological effects of pollution in the bay have been examined at 10 stations. The hydrographic studies included measurements of temperature, transparency, seston, salinity, nitrate, phosphorus and dissolved oxygen. The benthic animals collected belong to 108 species; most of them were polychaetes. Comparison of the stations reveals that species richness increases from very polluted regions towards cleaner waters.
\end{abstract}

\section{INTRODUCTION}

More than 650,000 people live around the inner Bay of Izmir at the western end of Anatolia. Their daily domestic wastes flow untreated into the sea via many canals and small streams. In addition, the dock of Izmir is a busy commercial centre. For these reasons, the pollution specifically caused by domestic sewage in the bay increases rapidly, and produces negative changes in abiotic and biotic factors of the bay waters.

Previous faunal studies conducted in the bay were concerned with crabs (Kocataş, 1971) and polychaetes (Ergen, 1976). The benthic communities of soft substrata were examined by Geldiay \& Kocataş (1972) and those of hard substrata by Kocataş (1978b). Besides this research, the physico-chemical characteristics of the polluted inner bay waters and the effects on benthic species were studied by Kocatass (1978a); further, the distribution of benthic forms affected by pollution was reported by Geldiay et al. (1979). In this presentation, physico-chemical and benthic properties observed during a twoyear study, from May 1977 to May 1979, are reported.

\section{STUDY AREA AND METHODS}

The Bay of Izmir may be topographically divided into an inner bay (harbour area) and an outer bay (Fig. 1). These two parts are linked by a narrow channel. The outer bay leads into the Aegean Sea through a wide opening. Since only a few thousand people live on these shores, the inner bay - which resembles a lagoon - was chosen as study area. Ten stations were selected on the basis of their presumed degree of pollution. Stations 1, 2 and 3 are located in the presumably most polluted eastern end of the bay; Stations $4,5,6,7$, and 8 are in relatively polluted waters; Station 9 is in waters with only a few domestic sewage canals; Station 10 is in the open waters of Yenikale which are relatively clean.

Physico-chemical data were determined monthly and benthic sampling was done simultaneously at the 10 stations chosen in the inner bay. 


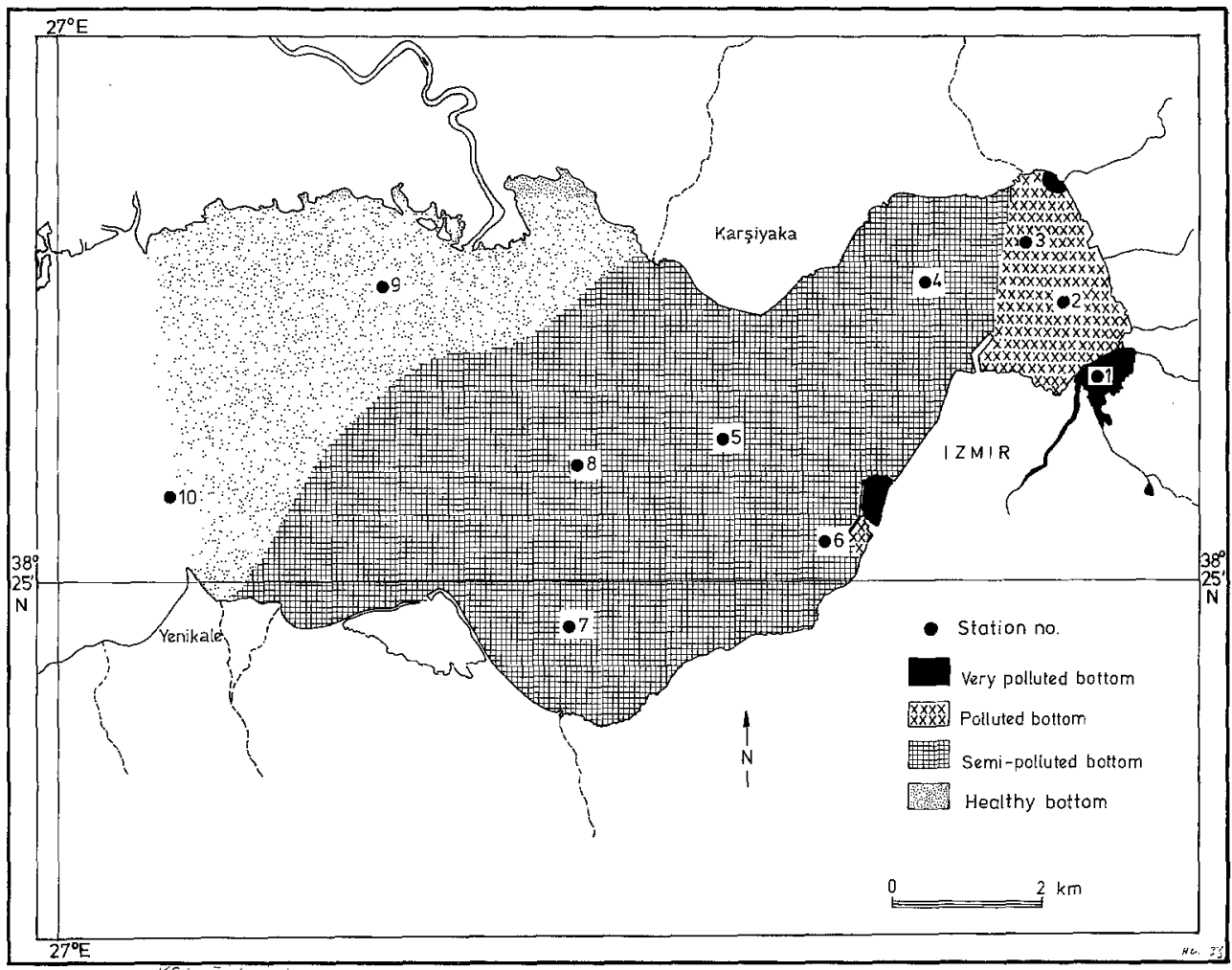

Fig. 1. Sampling stations and pollution zones in the Bay of Izmir

The follwing parameters were measured: temperature and salinity (portable temperature-salinity bridge); transparency (Secchi-disc); seston (Millipore HA 0.45- $\mu \mathrm{m}$ filter paper after processing at $60^{\circ} \mathrm{C}$ in oven); oxygen (Winkler method); $\mathrm{pH}$ ( $\mathrm{pH}$ meter), nitrate and phosphate (portable laboratory kit).

Benthic samples were taken monthly with an orange peel grab (capacity: 4.51 sediment). Two samples ( 91 ) of mud were strained through a sieve with $2-\mathrm{mm}$ mesh size. In the laboratory the sample contents were separated into systematic groups. Later, the species of each group were determined.

In order to determine and to compare the diversity of macrofauna, the formula $d=\frac{S-1}{\log _{\mathrm{e}} N}$ (Margalef, 1958) was used (where $S=$ number of species and $N=$ number of individuals).

\section{RESULTS AND DISCUSSION \\ Physico-chemical results}

Te mperature. The seasonal temperatures of the bay surface waters vary between $9^{\circ}$ and $27.5^{\circ} \mathrm{C}$ (Fig. 2). There are no significant differences ( $\pm 0.5^{\circ} \mathrm{C}$ ) between the stations examined. The annual average temperature is about $19^{\circ} \mathrm{C}$ (Fig. 6). 


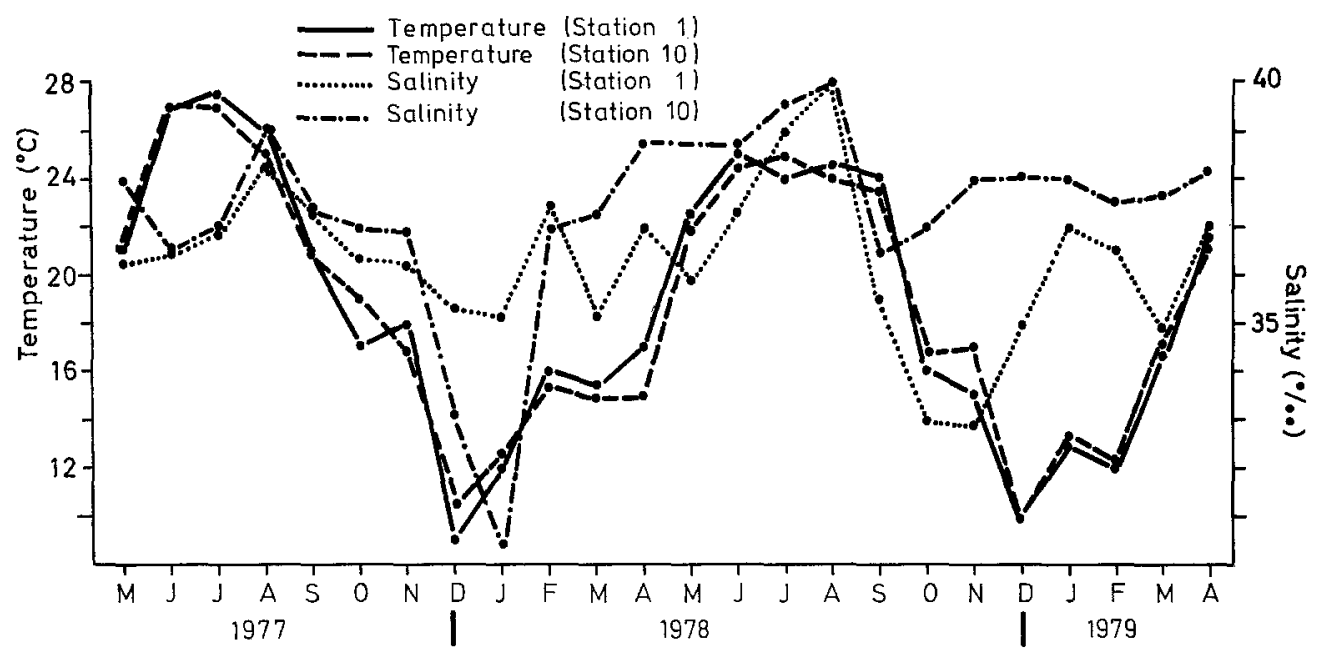

Fig. 2. Seasonal variations of surface temperature and salinity

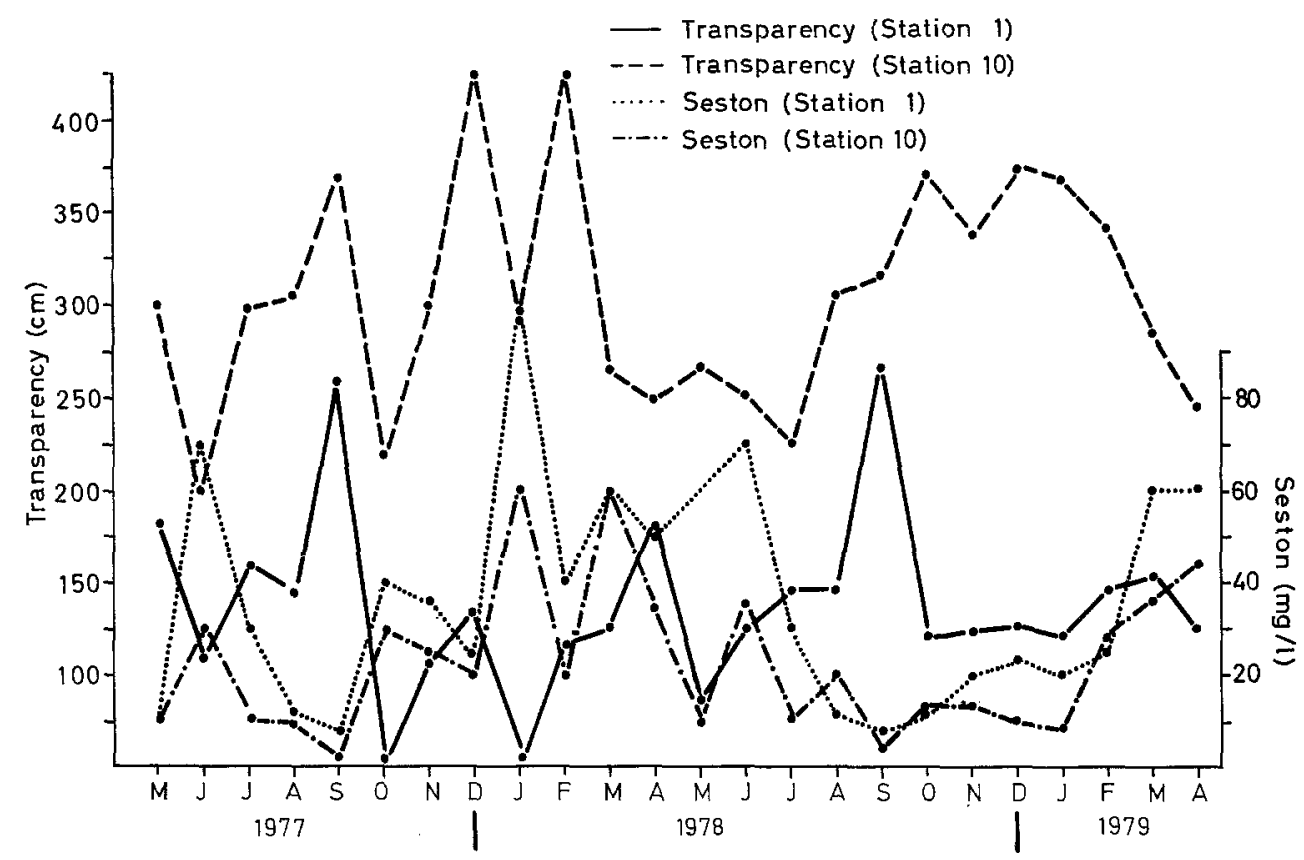

Fig. 3. Seasonal variations of transparency and seston values

Transparency. The great variability of this characteristic between stations reflects the varying degree of pollution (at Station 1 between 54 and $265 \mathrm{~cm}$, at Station 10 between 200 and $425 \mathrm{~cm}$; Fig. 3). In general the inner bay waters are more turbid in spring and summer but changes in transparency can also be observed during the course of one day. Transparency tends to increase from the inner to the outer regions. For 
example, the mean values at Stations 1 and 10 were $130 \mathrm{~cm}$ and $307 \mathrm{~cm}$, respectively (Fig. 6).

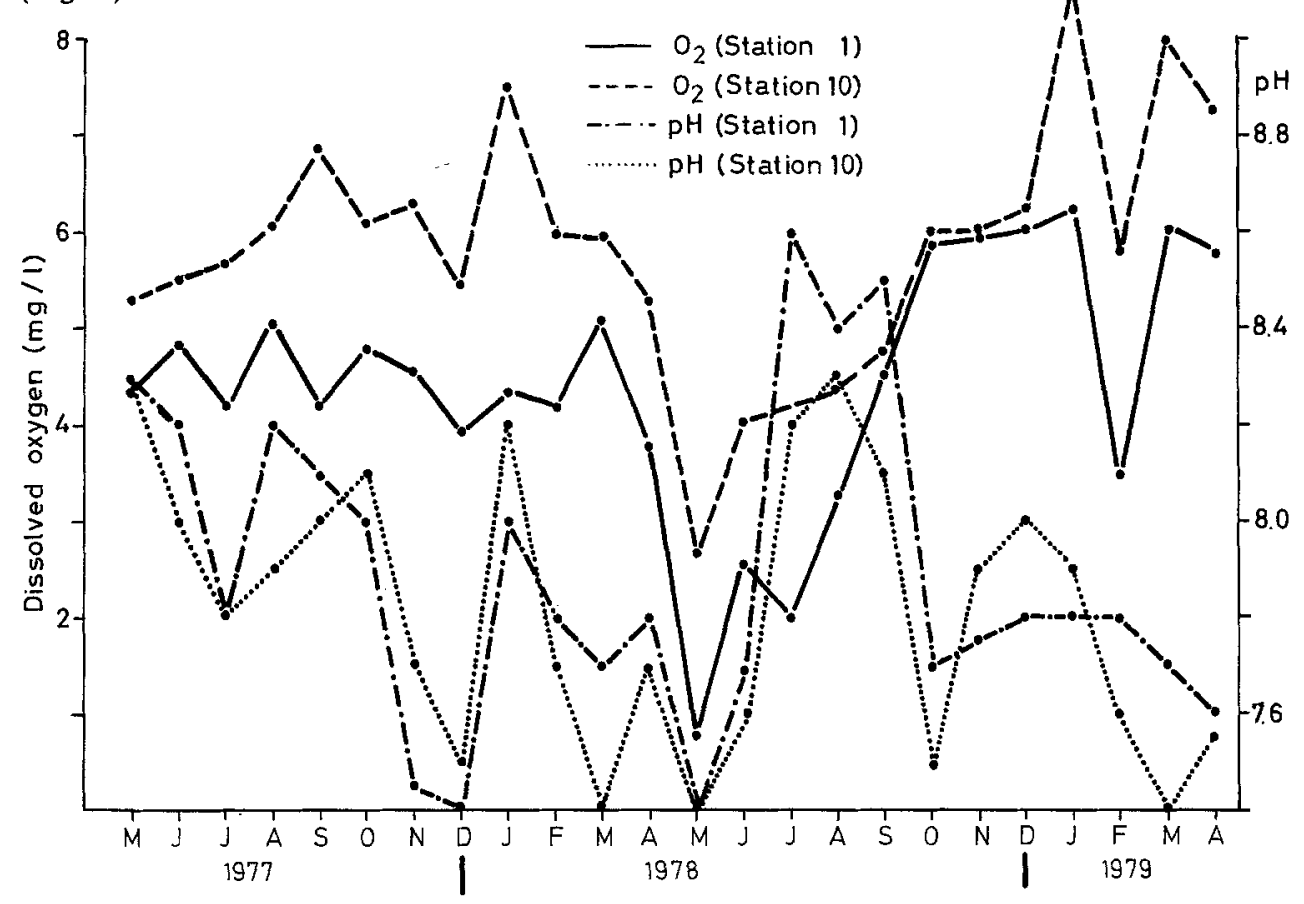

Fig. 4. Seasonal variations of surface oxygen and $\mathrm{pH}$

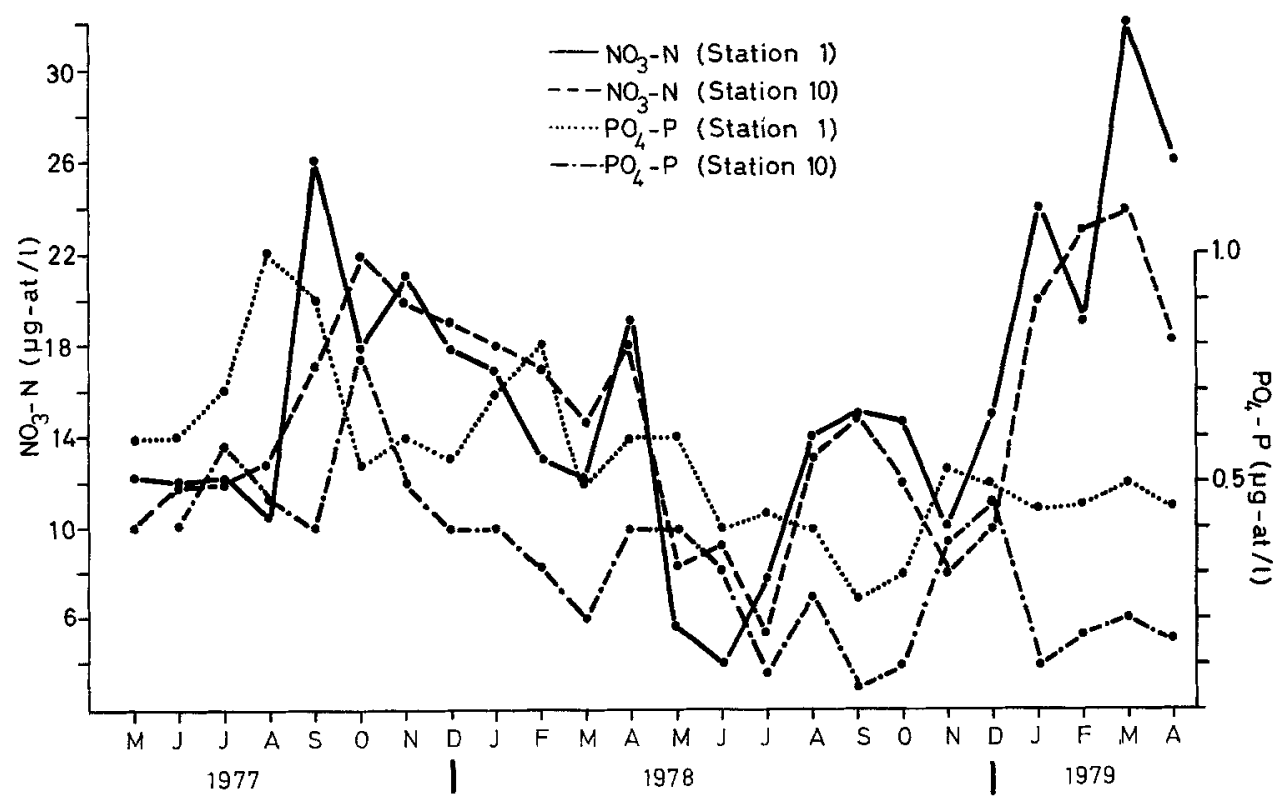

Fig. 5. Seasonal variations of nitrate-nitrogen and phosphate-phosphorus 

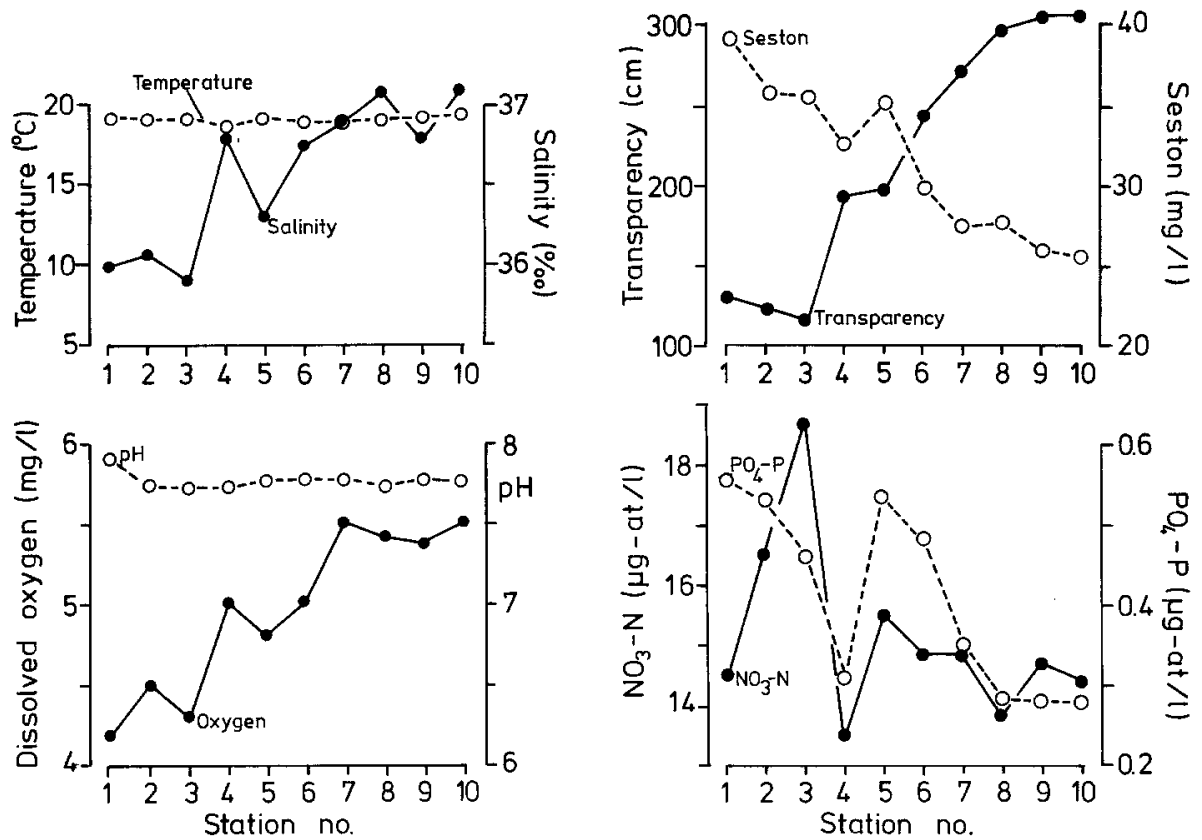

Fig. 6. Variations in the mean values of the physico-chemical parameters at each station (over 2 years)

S e st o n. The amount of seston varies with respect to season and station. Seasonal variations range between $4 \mathrm{mg} / 1$ and $100 \mathrm{mg} / \mathrm{l}$. In general, the quantity of seston in winter and spring is greater than in summer and autumn due to the addition of soil drainage waters to the domestic waste flow (Fig. 3). When the stations are compared as to their average seston values, a decrease is noted from the inner to the outer bay $(39 \mathrm{mg} / \mathrm{l}$ at Station 1, $25.2 \mathrm{mg} / \mathrm{l}$ at Station 10) (Fig. 6).

Salinity. The surface salinity of bay waters varies seasonally between $30.4 \%$ and $40.1 \%$. Surface temperature and precipitation cause maximum salinities in summer (Fig. 2). A small average increase has been observed from the inner to the outer regions (Fig. 6).

Oxygen. The quantity of oxygen dissolved in surface water shows important

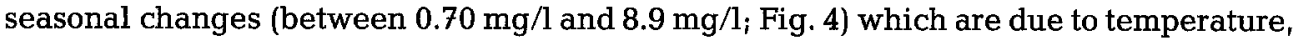
fluctuations of organic material, and changes in phytoplankton populations. There is an average increase from the inner to the outer areas (e. g. $4.8 \mathrm{mg} / \mathrm{l}$ at Station $1,5.5 \mathrm{mg} / \mathrm{l}$ at Station 10; Fig. 6).

$\mathrm{pH}$. Bay waters are slightly basic and the $\mathrm{pH}$ value varies seasonally between 6.9 and 8.6 (Fig. 4). The average $\mathrm{pH}$ values of all stations are about 7.7 (Fig. 6).

$\mathrm{Nitr}$ ate. This nutrient changes seasonally between 3.0 and $32.0 \mu \mathrm{g}$-at $/ 1$ in bay waters (Fig. 5). The average values from the stations did not show major differences (Fig. 6).

Ph os ph a te. Phosphate varies seasonally in the bay between 0.05 and $1.9 \mu \mathrm{g}$-at $/ \mathrm{l}$ (Fig. 5). From the inner areas to the outer a decrease has been observed (Fig. 6). 


\section{Biological observations}

Only benthic species of the inner bay were investigated; their distribution is closely related to the degree of pollution. Benthic sampling at the 10 stations comprised 15,653 individuals belonging to 108 species (Table 1). The mussel Arca (Scapharca) amygdalum, which immigrated to the bay several years ago, has an increasingly wide distribution. Of the 9119 molluscs found, 5735 individuals belong to this species. The numbers of mollusc and polychaete species increase from the inner towards the outer bay but the increase in crustacean species numbers is not as regular (Fig. 7). In contrast,

Table 1. Species distribution of major invertebrate taxa and individuals in Izmir Bay

\begin{tabular}{|lccrr|}
\hline Taxa & $\begin{array}{c}\text { Number } \\
\text { of species }\end{array}$ & $\begin{array}{c}\text { Percentage } \\
\text { of species }\end{array}$ & $\begin{array}{c}\text { Number } \\
\text { of individuals }\end{array}$ & $\begin{array}{c}\text { Percentage } \\
\text { of individuals }\end{array}$ \\
\hline Polychaeta & 52 & 48 & 5179 & 33 \\
Crustacea & 25 & 23 & 1231 & 8 \\
Mollusca & 21 & 19 & 9118 & 58 \\
Echinodermata & 4 & 4 & 113 & - \\
Ascidiacea & 2 & 2 & 7 & \\
Nemertini & 2 & 2 & 2 & 3 \\
Plathelminthes & 1 & 1 & 15653 & \\
\hline Cephalochordata & 1 & 1 & & \\
\hline$\Sigma$ & 108 & & & \\
\hline
\end{tabular}

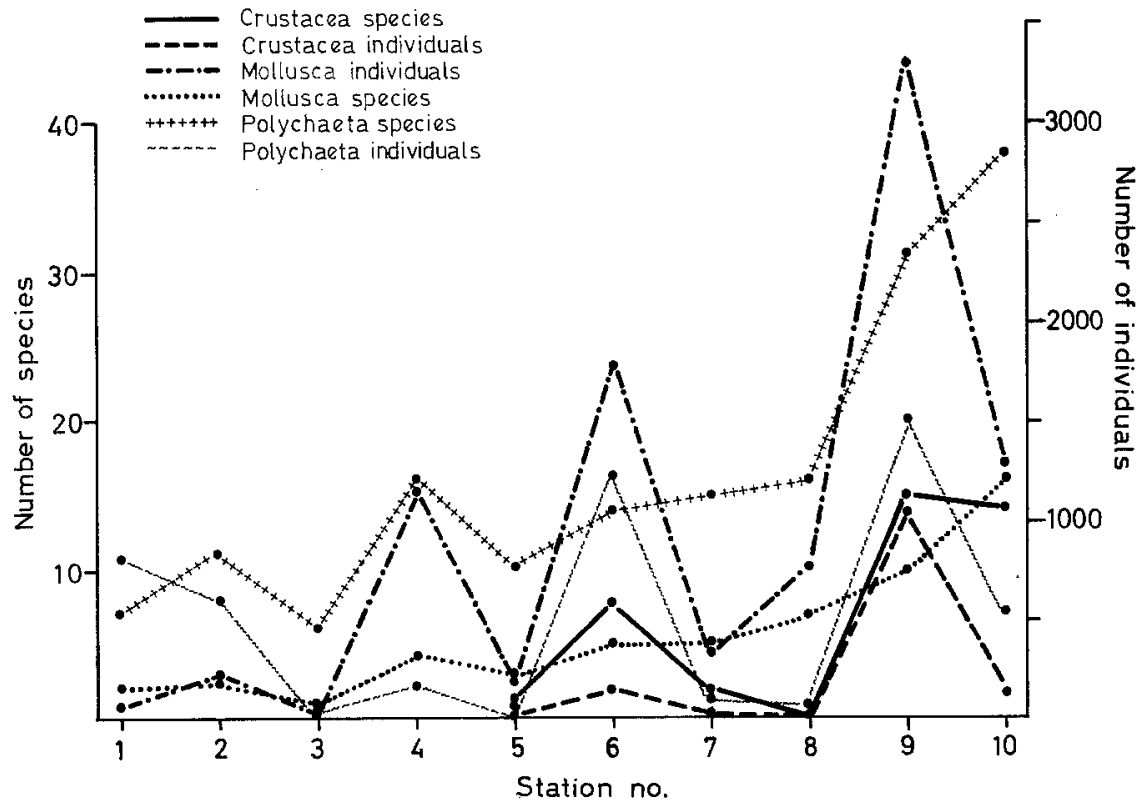

Fig. 7. Variations in the numbers of species and individuals of crustaceans, molluscs and polychaetes at each station 
the numbers of Mollusca and Polychaeta individuals vary greatly from station to station. These fluctuations are due to the nature of the substrata at the stations examined.

When the stations are compared as to total species richness, an increase is seen from the polluted to the clean zones (Fig. 8). While only 9 species were found at Station 1, 77 species were collected at Station 10.

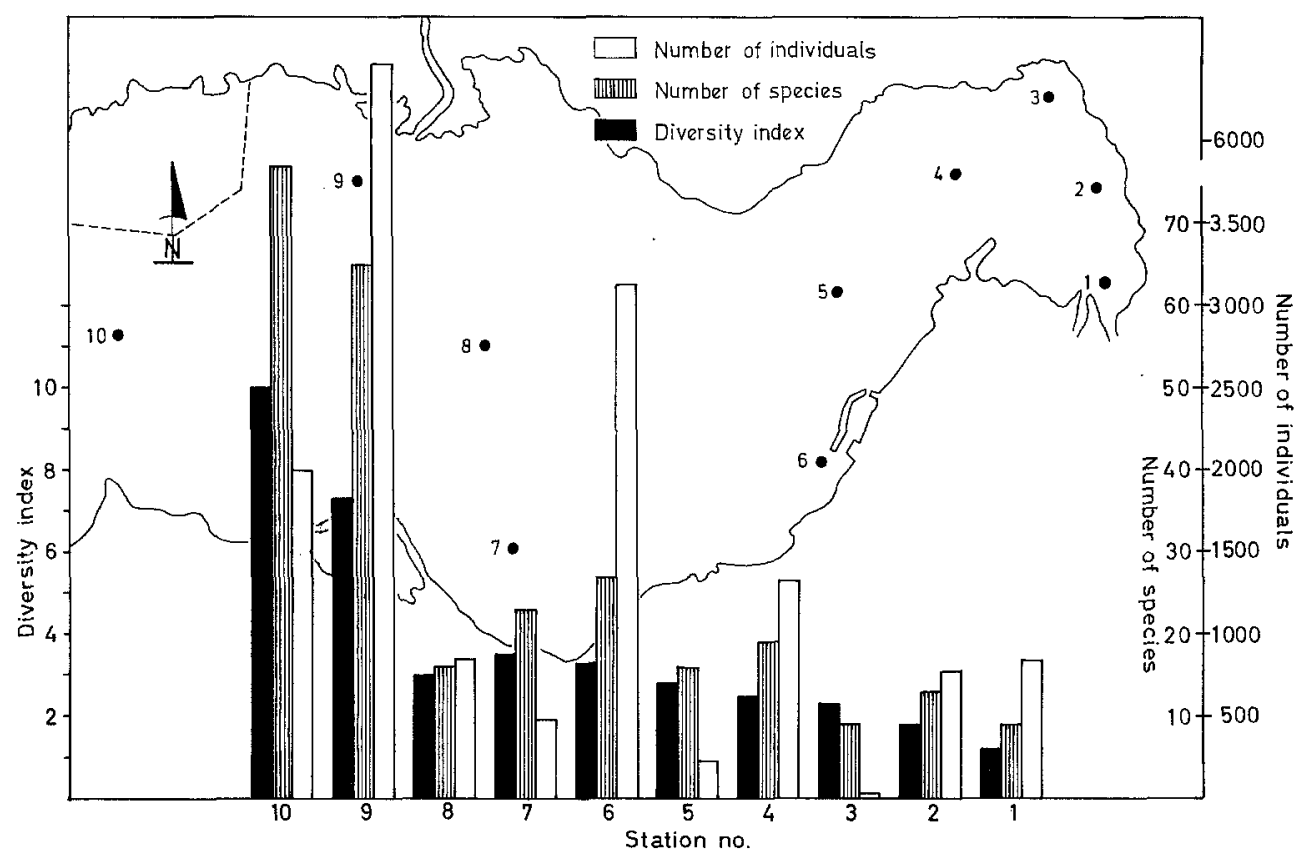

Fig. 8. Distribution of the total number of species and individuals at each station and the diversity index

This effect of pollution on the richness of fauna is also indicated by the diversity indices of the stations (Fig. 8). They increase from 1.18 at Station 1 to 10.0 at Station 10.

The degree of pollution can be described in terms of zones by comparing the number of benthic species and the type of substratum (see Reish, 1955, 1959, 1972; Bellan, 1967; Leppäkoski, 1975). In this region four zones can be distinguished:

(1) Very polluted bott om : No macrobenthic species have been found in this region, which encompasses areas in the harbour, the vicinity of Station 3, and the mouth of Halkapinar stream.

(2) Polluted b o t to m: This zone surrounding the vicinities of Stations 1 and 2 is characterised by the polychaete Capitella capitata, the total number of species varying between 5 and 6 .

(3) Semi-polluted bottom: This zone is located around the vicinities of Stations $4,5,6,7$ and 8 with species numbers of 16 to 28 . The characteristic species is the mollusc Corbula gibba.

(4) Healthy b ot to m: This zone is found in the vicinity of Stations 9 and 10 and the average number of species has been found to be about 70 . 
As follows from this situation, the very polluted bottom in Izmir Bay is a narrow area, the polluted bottom is a wider area, and the semi-polluted bottom covers a large region of the inner bay (Fig. 1).

The continuous flow of untreated sewage from domestic and commercial sources into the lagoon-like inner bay is expected to transform this region into an azoic zone in the near future. The consequences of this process will be fatal for the future existence of marine life in this area.

\section{LITERATURE CITED}

Bellan, G. 1967. Pollution et peuplement benthiques sur substrat meuble dans la région de Marseille. - Revue int. Océanogr. méd. 6-7, 53-87.

Ergen, Z., 1976. Investigations on the taxonomy and ecology of Polychaeta from Izmir Bay and its adjacent areas. - Scient. Rep. Fac. Sci. Ege Univ. 209 (135), 1-73.

Geldiay, R. \& Kocataş, A., 1972. Note préliminaire sur les peuplements benthiques du Golfe d'Izmir. - Scient. Monogr. Fac. Sci. Ege Univ. 12, 1-34.

Geldiay, R., Kocataş, A. \& Ergen, Z., 1975. Izmir Körfezinin Genel Hidrografi üzerinde ilk görüşler. TBTAK V. Bilim Kongresi, Ankara, 315-327.

Geldiay, R., Ergen, Z. \& Kocataş, A., 1979. Some effects of pollution on the benthic communities of the soft substrate in the Bay of Izmir (Turkey). - Rapp. P. v. Réun. Comun. int. Explor. Scient. Mer Méditerr. 25-26 (4), 195-196.

Kocataş, A., 1971. Investigations on the taxonomy and ecology of crabs "Brachyura" from Izmir Bay and its adjacent areas. - Scient. Rep. Fac. Sci. Ege Univ. 121 (76), 1-77.

Kocataş, A., 1978a. Distribution et évolution des peuplements benthiques du Golfe d'Izmir soumis à des multiples pollutions. C. I. E. S. M., Antalya, 417-421.

Kocataş, A., 1978b. Contribution à l'étude des peuplements des horizons supérieurs de substrat rocheux du Golfe d'Izmir (Turquie). - Scient. Monogr. Fac. Sci. Ege Univ, 12, 1-93.

Leppäkoski, E., 1975. Assessment of degree of pollution on the basis of macrozoobenthos in marine and brackish-water environments. - Acta Acad. åbo. B 35 (2), 1-90.

Margelef, R., 1958. Temporal succession and spatial heterogeneity in phytoplankton. In: Perspectives in marine biology. Ed. by A. A. Buzzati-Traverso. Univ. of California Press, Berkely, 323-349.

Pérès, J. M., 1976 (Ed.). La pollution des eaux marines. Gauthier-Villars, Paris, 227 pp.

Reish, D. J., 1955. The relation of polychaetous annelids to harbor pollution. - Publ. Hlth Rep. 70, 1168-1174.

Reish, D. J., 1959. An ecological study of pollution in Los Angeles - Long Beach Harbors, California. - Occ. Pap. Allan Hancock Fdn 22, 1-119.

Reish, D. J., 1972. The use of marine invertebrates as indicators of varying degrees of marine pollution. In: Marine pollution and sea life. Ed. by M. Ruivo. Fishing News Books, London, 203-207. 